\title{
THE CORRELATION BETWEEN STUDENTS' INTELLIGENCE LEVEL AND THEIR ACHIEVEMENT IN LEARNING ENGLISH
}

\author{
Ahmad Junaedi \\ Universitas Sulawesi Barat \\ Email: ahmad4future@gmail.com
}

\begin{abstract}
The objective of the research was to find out the correlation between the students intelligence and their achievement in learning English at SMPN 27 Makassar. The design of this research was descriptive and employed correlational method. The population of this research was the second year students of SMPN 27 Makassar. The technique of sampling applied cluster random sampling which the total of sample was 20 students. The instruments of this research were IQ test and English test. To find out students achievement in learning English, the researcher tested the students using multiple choice test that consisted of materials from their handbook. To find out the level of students intelligence, the Psychological Department Team of State University of Makassar was given IQ test. To find out the correlation from both variables, the researcher used Pearson $r$ formula. The result of the test shows that most of the students' intelligence was categorized as dull average and the students' achievement was 6.35 which is categorized as fair achievement. The result data found that there was no significant correlation between the students' intelligence level and their achievement in learning English at the second year of SMPN 27 Makassar. It caused by some factors like health, social differences, motivation, ethnic differences, motivation, heredities, quality of instruction, family resources, parental support, and so on.
\end{abstract}

\section{Keywords: intelligence; academic; achievement}

\section{INTRODUCTION}

\subsection{Introduction}

The cognitive development is genetically process, which is one process based on biological mechanism, the growth of neutron system. The more the age develops the more complex the neutron systems organize themselves. The process makes the ability and knowledge possible to increase because the intellectual function growth consisting of knowledge, comprehension, application, analysis, synthesis and evaluation is becoming complex, too. However, the learning process will follow the pattern and phase of certain development as suitable as the learners' age. (Piaget: 1950) 
In line with learning a foreign language, the intelligence is a potentiality which is very necessary to be owned by the students. Intelligence covers the capacity of thinking, learning, and understanding something. Smith in Rahmatullah (1997) stated that the students cannot enter the foreign language program unless they have an IQ of at least a hundred and twenty three.

From observation, researcher get information from SMPN 27 Makassar teachers that intelligence level of their students' is normal. That statement is supported by Misrawati in her research, improving the listening comprehension achievement of students of SMPN 27 Makassar through story telling. She found that the ability of the second year's students of SMPN 27 Makassar in learning English is average.

The students who have low intelligence may regard teaching materials are difficult although the teacher has designed and presented them as good as possible. Due to their difficulties to comprehend the materials, teachers explanation may reflect or cause them have negative attitude toward English language teaching. While the students who have normal intelligence, may try to overcome difficulties that they face. Having a good intelligence, students gain development because of their power to comprehend the materials presented. In short, the internal factor of the students like interest, behavior, aptitude, age development and intelligence has a big effect in supporting the success of students in learning.

Based on the description above, the writer tries to find there is the correlation between students' intelligence level and their achievement in learning English or not.

\subsection{Research questions}

Based on the background above, the researcher formulates some research questions, as follows:

1. How is the intelligence level of the students?

2. How is the students' achievement in English?

3. What is the correlation between students' intelligence level and their achievement in English?

\subsection{Significance of the study}

This research is expected to give significant contribution for the language learning and teaching process. As the result, both the teachers and students understand more about the intelligence. Then, the teachers can design new local curriculum based on students need by considering the cultural value of the students. Besides, the students can improve their achievement with new strategy in accordance with the intelligence level they have.

\section{METHOD}

\subsection{Research Design}


This research employed correlation method which involves collecting data in order to test the variables of the research. It raised from the researcher mind whether there is significant correlation between the students' intelligence level with their achievement in learning English or not.

\subsection{Samples/Participants}

From 8 classes in the second year students, the numbers of the students were 225 then the writer took 20 students randomly. The writer used simple random technique.

\subsection{Instruments}

In order to collect data, English test and IQ test result was used. The first was to find the students' achievement in English test. And the second test was to find out students' IQ score reflecting their intelligence.

The IQ test was given by the Psychological Department Team of State University of Makassar in order to reach an available and acceptable result or the valid one. The English test consists of 50 items. They are all in multiple-choice design. This involves 4 skills and two elements of language.

\subsection{Data analysis}

The data derived from both test were analyzed quantitatively employing statistical calculation. The steps in analyzing the data are chronologically conveyed as follows:

a. Scoring the test

In scoring the English test which consist of 50 items the researcher gave two points for one correct answer. Thus, the total score will be 100 points as raw scores.

b. Classifying the students' score

The score achieved by the students in the English test were classified as follows:

$\begin{array}{lll}\text { Scores } & 9.6-10 & \text { is classified as excellent } \\ \text { Scores } & 8.6-9.5 & \text { is classified as very good } \\ \text { Scores } & 7.6-8.5 & \text { is classified as good } \\ \text { Scores } & 6.6-7.5 & \text { is classified as fairly good } \\ \text { Scores } & 5.6-6.5 & \text { is classified as fair } \\ \text { Scores } & 3.6-5.5 & \text { is classified as poor } \\ \text { Scores } & 0.0-3.5 & \text { is classified as very poor }\end{array}$

(Kanwil Depdikbud, 2004) 
The students' score in IQ test were classified as follows:

$\begin{array}{lll}\text { Scores } & >146 & \text { is classified as genius } \\ \text { Scores } & 128-145 & \text { is classified as very superior } \\ \text { Scores } & 110-127 & \text { is classified as superior } \\ \text { Scores } & 92-109 & \text { is classified as average } \\ \text { Scores } & 74-91 & \text { is classified as dull average } \\ \text { Scores } & 56-73 & \text { is classified as border line } \\ \text { Scores } & 38-55 & \text { is classified as moron } \\ \text { Scores } & 20-37 & \text { is classified as imbecile } \\ \text { Scores } & <19 & \text { is classified as idiot } \\ & & \text { (Sumadi, 1995) }\end{array}$

c. Calculating the mean score

The find out the mean score of each test, the following formula was used:

$\overline{\mathrm{x}}=\frac{\sum x}{N}$

Notation:

$$
\begin{aligned}
& \overline{\mathrm{x}}=\text { Mean score } \\
& \sum x=\text { Total of raw score } \\
& \mathrm{N} \quad=\text { The number of sample }
\end{aligned}
$$

(Kanwil Depdikbud, 2004)

d. Calculating the correlation

To know whether there is significant correlation between students' intelligence and their achievement in learning English, the following formula was applied:

$$
r=\frac{\sum X Y-\frac{\left(\sum X\right)\left(\sum Y\right)}{N}}{\sqrt{X^{2}-\frac{\left(\sum X\right)^{2}}{N} Y^{2}-\frac{\left(\sum Y\right)^{2}}{N}}}
$$

Notation:

$$
\begin{aligned}
\mathrm{r} & =\text { Pearson } \mathrm{r} \\
\sum X \quad & =\text { The sum of the score in } \mathrm{X} \text { distribution }
\end{aligned}
$$




$$
\begin{array}{ll}
\sum Y & =\text { The sum of the score in } \mathrm{Y} \text { distribution } \\
\sum X Y & =\text { The sum of the product paired } \mathrm{X} \text { and } \mathrm{Y} \text { score } \\
\sum X^{2} & =\text { The sum of the square in } \mathrm{X} \\
\sum Y^{2} & =\text { The sum of the square in } \mathrm{Y} \\
\mathrm{N} & =\text { The number of sample }
\end{array}
$$

To interpret the result of the correlation analysis the standard correlation Pearson $r$ was used:

\begin{tabular}{lll} 
No. & \multicolumn{1}{c}{ Standard } & Interpretati \\
1 & $0.000-0.200$ & Very Low \\
2 & $0.200-0.400$ & Low \\
3 & $0.400-0.600$ & Moderate \\
4 & $0.600-0.800$ & Substantial \\
5 & $0.800-1.000$ & High
\end{tabular}

(Hadi, 1979)

If the $\mathrm{r} x \mathrm{y}$ lies between $0.400-1.000$, the $\mathrm{H} 1$ is received. If the $\mathrm{r} \mathrm{x} \mathrm{y}$ lies between $0.000-0.400$, the $\mathrm{H} 1$ is rejected. If the $\mathrm{H} 0$ is rejected, it means that there is a significant correlation between the students' intelligence level and their achievement in learning English. To see if the correlation between two variables of this study is significant or not. The $r$ analysis is compared to the $r$ table.

If $\mathrm{r} x \mathrm{y}>\mathrm{r}$ table, the correlation is positive

If $\mathrm{r} x \mathrm{y}<\mathrm{r}$ table, the correlation is negative

If $\mathrm{r} x \mathrm{y}>\mathrm{r}$ table, the correlation is zero

\section{FINDINGS AND DISCUSSION}

\subsection{Findings}

This section presents the answer of problem statements. Those are students' intelligence level, English achievement and correlation both of them.

\section{Intelligence Level}

The data analysis shows that the intelligence levels was dominantly in dull average $(85 \%)$ as indicated by the mean score of intelligence test 82.65 , that can be seen in the following calculation. 
The mean score of intelligence test was achieved by dividing the sum of all scores to the subjects total number was in the following calculation:

$$
\begin{aligned}
\overline{\mathrm{X}} & =\frac{\sum x}{N} \\
& =\frac{1653}{20} \\
& =\mathbf{8 2 . 6 5}
\end{aligned}
$$

The calculating above shows that the mean score of the second year students of SMPN 27 Makassar on IQ test is 82.65. This mean score was classified as dull average. It reveals that the second year students of SMPN 27 Makassar have dull average IQ.

Furthermore, the frequency and percentage of the students' intelligence level can be seen in the following table:

Table 1. The frequency and Percentage of the Students' Intelligence Level

\begin{tabular}{cccc}
\hline Grade & Classification & Frequency & Percentage \\
\hline I & Genius & 0 & $0 \%$ \\
II & Very Superior & 0 & $0 \%$ \\
III & Superior & 0 & $0 \%$ \\
IV & Average & 3 & $15 \%$ \\
V & Dull Average & 17 & $85 \%$ \\
VI & Border Line & 0 & $0 \%$ \\
VII & Moron & 0 & $0 \%$ \\
VIII & Embicile & 0 & $0 \%$ \\
IX & Idiot & 0 & $0 \%$ \\
\hline
\end{tabular}

Table 1 above shows that none of the students was classified in genius (grade 1), very superior (grade II), superior (grade III), border line (grade VI), moron (grade VII), embicile (grade VIII) and idiot (grade IX). The highest percentage of the classification is 
dull average (grade V) that is $85 \%$ or 17 students. There are 3 students (15\%) who obtain in grade IV (average).

\section{English Achievement}

The data analysis shows that the English achievement levels was in fair level $(55 \%)$ as indicated by the mean score of English achievement 6.35, that can be seen in the following calculation.

The mean score of English achievement test was achieved by dividing the sum of all scores to the subjects' total number was in the following calculation:

$$
\begin{aligned}
\overline{\mathrm{X}} & =\frac{\sum x}{N} \\
& =\frac{127}{20} \\
& =\mathbf{6 . 3 5}
\end{aligned}
$$

The calculating above shows that the mean score of the second year students of SMPN 27 Makassar on English test is 6.35. This mean score was classified as fair. It reveals that the second year students of SMPN 27 Makassar have fair achievement in learning English.

Furthermore, the frequency and percentage of English test achievement can be seen in the following table:

Table 2. The frequency and percentage of the English test achievement

\begin{tabular}{ccccc}
\hline No. & Classification & Score & Frequency & Percentage \\
\hline 1 & Excellent & $9.6-10$ & 0 & $0 \%$ \\
2 & Very Good & $8.6-9.5$ & 0 & $0 \%$ \\
3 & Good & $7.6-8.5$ & 0 & $0 \%$ \\
4 & Fairly Good & $6.6-7.5$ & 11 & $55 \%$ \\
5 & Fair & $5.6-6.5$ & 6 & $30 \%$ \\
6 & Poor & $3.6-5.5$ & 3 & $15 \%$ \\
7 & Very Poor & $0.0-3.5$ & 0 & $0 \%$ \\
\hline
\end{tabular}


Table 2 above shows that there are $0(0 \%)$ of the students get excellent, very good and good scores. There are $11(55 \%)$ students get fairly good scores. There are 6 (30\%) students get fair scores. There are $3(15 \%)$ students get poor score and none of the students get very poor score.

\section{The Correlation Between Intelligence Level and Achievement}

The analyzing of the Pearson $r$ formula shows the correlation between the students achievement in learning English and their intelligence level was found that:

$$
\begin{aligned}
& r=\frac{3.45}{181.82} \\
& r=\mathbf{0 . 0 1 8}
\end{aligned}
$$

The $\mathrm{r}$ value was in very low level correlation lying between $0.000-0.200$ and the result is consulted to the " $r$ " table value with the degree of freedom $(\mathrm{df})=20-2=18$ and $\rho=0.5$ it is 0.4438 compared to 0.018 . Because rxy lower than $r$ table, $\mathrm{H}_{0}$ is accepted. It means there is no significant correlation between the intelligence level of the second year students of SMPN 27 Makassar and their achievement in learning English is received.

\subsection{Discussion}

This section presents the explanations of problem statements. Those are students' intelligence level, English achievement and correlation both of them.

\section{Intelligence level}

In data analysis, intelligence level of the students was dominantly in dull average and average level. It might happen because some influencing factors as genetic factors, home environment, social, class differences and ethnic differences, but genetic/heredities factors is very dominant.

In line with these factors, supported by Ben Han in Nurkancana and Sumartana (1986) said that genetic factor of a mother really influence the intelligence level of a child because it is related to the chromosome carried by her, so an intelligent mother has a big potential to bear intelligent children too. This statement also supported by the result of the research of some psychologist, such as Lochlin, Lindzey and spuhler in Prabu (1993) that about 75-80\% of intelligence level is heredities factor. 


\section{English Achievement}

In data analysis, English achievement of the students was dominantly in fairly good and fair score. It might come on the surface because the students did not have time preparing themselves before having the test. The researcher informed them about the test at the time they have to do it.

The fairly good and fair score by the second year students of SMPN 27 Makassar in learning English were poor mentally ready of performing the test. The students need more concentration and motivation. The test involves four skills and two elements of language. Hence, all the factors above were not investigated by the researcher when gathering the data. Those would be other factors that caused the fair achievement of the second year students of SMPN 27 Makassar in English test.

Statement above supported by Suryabrata (2012:172) states that academic achievement can be classified into two, internal factors and external factors. Internal factors; Susanto (2014:12) stated Internal factor come from the students themselves, which affects their learning ability, in which includes physiology aspect and psychology aspect. Physiology aspect related to the five senses and health. Students' physical condition is considered as one of factors that influence achievement. Psychology aspect in affecting achievement which is considered is intelligence, motivation attitude, aptitude and interest. External factors; factors that come from outside the students themselves, includes family, social and non-social environment

\section{Correlation between students intelligence level and achievement}

In data analysis, intelligence level of the students was dominantly in dull average and average level, but English achievement of the students was dominantly in fairly good and fair score. Both of them were in middle classification. It means that the intelligence level and English achievement of the students at SMPN 27 Makassar are low correlation. It occurs because rxy is lower than $r$ table. The low of rxy indicated that the ability of the students to answer the IQ test and English test are low too. So the degree of correlation depends on the result of IQ test and English test.

There are many experts believe that intelligence plays an important role in creating a successful learning process, like Kolesnik in Slameto (2003) said that in most cases there is a fairly high correlation between one's IQ and his scholastic success. But research at SMPN 27 Makassar recently, shows a different findings. 
The data analysis indicate there is no significant correlation between students intelligence level and their achievement. This research was supported by Hamriati (1998) in her research, the correlation between students' intelligence score and the students reading comprehension ability. The different finding caused by some factors like health, sex, social differences, motivation, ethnic differences, motivation, heredities, quality of instruction, family resources, parental support, and so on are also involved.

\section{CONCLUSIONS}

\subsection{Conclusion}

Considering the data findings and discussion, the researcher put toward conclusion that the intelligence level of the students of SMPN 27 Makassar was classified as dull average, it is shown by the highest level percentage of intelligence score classification, it was $85 \%$ which lies between 74-91. Then, the English students' achievement of SMPN 27 Makassar was fair. It was reflected by the mean score 6.35, which lies between 5.6-6.5. The highest level percentage of achievement score classification was 55\% (11 students). It means that the correlation between the students' intelligence level and the students achievement in English is low, which means that there is any correlation but that is not main factor which influence students' achievement. The conclusion showed that the students with has lower IQ score do not always get lower score in English achievement and the students with higher IQ score also do not guarantee that they will get higher score in English achievement.

\subsection{Suggestions}

By considering the conclusion given above, the researcher presents some suggestions that the English teachers should be creative and proactive to manage seriously the students in teaching and learning process and also enrich English materials. For future researcher, the writer suggests to conduct further studies on this topic. Future research may investigate the same topic, but with different data so that the result will be more valid.

\section{REFERENCES}

Azimifar, M. (2013). The Relationship between Emotional Intelligence and Academic Achievement among Iranian Students in Elementary School. European online journal of natural and sciences, 2(2) 216-222

Depdiknas. (2004). GBPP Bahasa Inggris. Jakarta: Dikdasmen.

Gay, L. R. (2006). Educational Research. Florida: Pearson Education Inc. 
Hadi, Sutrisno. (1979). Metodologi Research untuk Penelitian Paper, Skripsi dan Disertasi. Yogyakarta: Gajah Mada Universitas Press.

Hamriati, H. (2004). The Correlation Between the Students Intelligence Score and the Reading Comprehension Ability. Unpublished thesis.

Laidra, K., H. Pullmann. \& J. Allik, (2007). Personality and intelligence as predictors of academic achievement: A cross-sectional study from elementary to secondary school. Personality and Individual Differences, 42(3), 441-451.

Nurkancana, Wayan and Sumartana. (1996). Evaluasi Pendidikan, 4th edition. Surabaya: Usaha Nasional.

Nur, Rahmatullah. (2007). The Correlation Between the Attitude of the Students of SPKS Toward English and Their English Achievement. Unpublished thesis.

Piaget, J. (1950). The Psychology of Intelligence. London: Routledge.

Prabu, A. Anwar Mangkunegara. (1993). Perkembangan intelligensi anak dan pengukuran IQnya. Bandung: Angkasa

Slameto. (2003). Belajar dan Faktor-faktor yang mempengaruhinya. Jakarta: Rineka Cipta.

Sumadi, Suryabrata. (1995). Psikologi Pendidikan, 7th edition. Jakarta: Raja Grafindo Persada. 